\title{
Assessment of Seed Hardening Treatments on Seed Quality in Chickpea (Cicer arietinum L.)
}

\author{
Kandula Uma Maheswari ${ }^{*}$, J. Hemasruthi ${ }^{1}$, Arun Kumar Chaurasia ${ }^{1}$, \\ P. Vineela ${ }^{1}$ and Y. Bharath Chandu ${ }^{2}$
}

\author{
${ }^{1}$ Department of Genetics and Plant Breeding, Naini Agricultural Institute, Sam Higginbottom \\ University of Agriculture, Technology and Sciences, Prayagraj, U. P., India \\ ${ }^{2}$ State Institute for Management of Agriculture, Department of Agriculture, Government of \\ Uttar Pradesh, India \\ *Corresponding author
}

\section{A B S T R A C T}

\begin{abstract}
Germination and Seedling emergence are the important phases in plant life cycle. Exploring ways to achieve uniformity and synchrony of plant growth under stress conditions is important. This prompted to assess the potential of pre-sowing seed treatments in improving germination and early seedling growth of Chickpea. Thus, an investigation was carried out to examine the effect of seed hardening treatments on seed quality on Chickpea at Post Graduate Laboratory and Field Experimentation Centre of Department of Genetics and Plant Breeding, Sam Higginbottom University of Agriculture, Technology and sciences, Allahabad (U.P.). Seeds were hardened with different solutions viz., Control, distilled water, $2 \% \mathrm{CaCl}_{2}, 2 \% \mathrm{KH}_{2} \mathrm{Po}_{4}, 1 \%$ $\mathrm{KNO}_{3}, 2 \% \mathrm{Kcl}, 2 \% \mathrm{ZnSo}_{4}, 200 \mathrm{ppm}$ salicylic acid, $200 \mathrm{ppm} \mathrm{GA}, 2 \% \mathrm{MgSo}_{4}, 5 \%$ Neem leaf extract, 5\% tulsi leaf extract and 5\% Aloevera leaf extract were taken and in their solutions seeds were hydrated for 12 hours and then dried back to their original moisture content. The results showed that seed hardening treatment of chickpea before sowing significantly increased the seed quality characteristics. The study revealed that seed hardened with $2 \% \mathrm{CaCl}_{2}\left(\mathrm{~T}_{2}\right)$ showed better performance in maximum seed quality parameters such as Germination percentage, Speed of germination, Coefficient of velocity of germination, Germination index, Shoot length, Root length, Seedling length, Seedling fresh weight, Seedling dry weight, Seedling vigour index and low Mean germination time followed by $\mathrm{KNO}_{3} @ 1 \%$ and 5\% Neem leaf extract when compared to other treatments and control on the basis of lab studies. However, Neem leaf extract and $\mathrm{KNO}_{3}$ is at par with $\mathrm{CaCl}_{2}$. Hence, seed hardening can be adopted as a regular practice to boost the yield of rainfed crops. It also helped to improve the seedling character and growth with the help of seed Hardening treatments which are cost effective, economic, non-toxic and from eco-friendly sources.
\end{abstract}

\section{Introduction}

Pulse crops play an important role in Indian agriculture as they are an important source of protein, grow quickly, generate good profits for farmers, and contribute to agricultural and environmental sustainability. Pulse is derived from the Latin word puls or pultis meaning pottage i.e., seeds boiled to make porridge or thick soup and refers only to the dry edible 
seed in the pod. They provide about $10 \%$ of the total dietary protein consumed in the world and have about twice the protein content of most cereals and considered as "Poor man's meat" due to their protein profile. The United Nations, Food and Agriculture Organization (FAO) has recognized 11 primary pulses and declared 2016 as the "International Year of Pulses" recognizing their role in nutritional security and sustainability of agriculture production.

Among the pulse's chickpea is the $3^{\text {rd }}$ most important food legume crop grown all over the world after dry beans and peas. It occupies a prime position in terms of production in India (FAO, 2012). Chickpea (Cicer arietinum L.) commonly known as gram, Bengal gram or Garbanzo beans belong to fabaceae family and had originated probably from South East Turkey. Chickpea is a selfpollinated true diploid $(2 n=16)$ major rabi season crop with genome size of approximately 740Mbp. Two varieties of chickpea are separated on the basis of seed size, colour, taste and belong broadly to two types namely Kabuli and Desi.

In the world, at present the Chickpea production is 17.19 million tonnes in an area of $17.81 \mathrm{M}$ ha and the average productivity is $9651 \mathrm{~kg}$ per hectare where as in India Chickpea is grown in $11.89 \mathrm{M}$ ha, the production level is 11.38 million tonnes with average productivity of $9564 \mathrm{~kg}$ per hectare (FAO STAT 2018). The average yield of chickpea in India is low due to its cultivation as rainfed crop or on receding soil moisture in cool dry season hence they frequently experience terminal moisture stress condition. Poor seed germination, insufficient seedling emergence, inappropriate stand establishment and low plant growth are the major constraints in chickpea because of its thin seed coat, low vigour, viability and susceptibility to soil borne pathogens. Unavailability of quality seeds in addition to soil moisture is a major drawback which limits the chickpea production. Hence, there is an urgent need to concentrate the work on how best the seed quality can be enhanced by using simple technology.

Seed Quality is a multiple concept comprising of several seed components like physical, biochemical and physiological characters (Sandhya, 2009). High quality seed is essential for successful agriculture which demands each and every seed should be readily germinable and produce a vigorous seedling ensuring high yield.

Seed invigoration in scientific literature is ascribed to beneficial treatments applied to seed after harvest but prior to sowing that improve germination or seedling growth or facilitate the delivery of seeds or other materials required at the time of sowing. It aims to improve seed germination and seedling growth, encompasses many techniques performed on seed after harvest and before sowing.

Pre-sowing seed hardening technique is one of the invigoration techniques that involves repeated soaking and control seed hydration in solution containing organic or inorganic solutes followed by redrying to fix the biochemical events that allow pre-germinative metabolic activities but prevent radical emergence (Basra et al., 2005). It modifies physiological, metabolical and biochemical nature of seeds thus enhances seed vigour by protecting plasma membrane against injury. As a result of extensive physiological reorganization it is found to be efficient in seed emergence and growth of crops.

Pre sowing seed hardening treatment is an easy, low cost and low risk technique and also an alternative approach recently used to overcome the effect of abiotic stresses in agricultural production. It is found to be efficient in improving seed emergence and 
growth of crops. (Sankar Ganesh et al., 2013). The hardening treatments accelerates rapid germination and growth rate of seedling, better root growth, increase crop population, reduces seedling mortality, flowering is slightly accelerated, seeds are able to withstand higher temperature, by emerging early, seedling will be able to compete more efficiently with weeds and thereby plants enhance growth and productivity potential of the crop varieties.

\section{Materials and Methods}

The present investigation entitled Assessment of seed hardening treatments on seed quality in chickpea (Cicer arietinum, L) was conducted during rabi season in 2019-20 in Seed Science and Technology laboratory at Department of Genetics and Plant Breeding, Sam Higginbottom University of Agriculture, Technology and Sciences, Prayagraj, Uttar Pradesh. The experimental material consists of 13 treatments including control viz., Control, distilled water, $2 \% \mathrm{CaCl}_{2}, 2 \%$ $\mathrm{KH}_{2} \mathrm{Po}_{4}, \quad 1 \% \quad \mathrm{KNO}_{3}, 2 \% \mathrm{Kcl}, 2 \% \quad \mathrm{ZnSo}_{4}$, 200ppm salicylic acid, 200 ppm GA $3,2 \%$ $\mathrm{MgSo}_{4}, 5 \%$ Neem leaf extract, 5\% tulsi leaf extract and 5\% Aloevera leaf extract.

\section{Preparation of solutions}

For preparation of solution, the required chemicals have been collected. The stock solutions of Calcium Chloride, Potassium dihydrogen phosphate, Potassium Nitrate, Potassium Chloride, Zinc Sulphate, Magnesium Sulphate, Gibberellic acid, Salicylic acid were prepared by taking into considerations their active ingredients by dissolving in the distilled water as per their required concentrations. Absolute water was also used for seed hardening treatment. The stock solutions were covered with muslin cloth to avoid any contamination. For the preparation of botanical leaf extracts, Tulsi,
Neem, Aloevera leaves were collected from Horticulture Research fields, SHUATS. These leaves were shade dried and made into fine powder.5g of each powder is dissolved in $100 \mathrm{ml}$ of distilled water to make $5 \%$ solution. Aloevera leaf extract is prepared by grinding $5 \mathrm{~g}$ of aloevera with $100 \mathrm{ml}$ of distilled water.

\section{Soaking of the seed in Solution}

After preparation of chemical and botanical solutions, Chickpea seeds were soaked in the respective solutions, mixed thoroughly and allowed to absorb moisture for 12 hours at room temperature. Untreated seed is called as control. After 12 hours of soaking the solution was drained out from the beaker and the presoaked seeds were spread out in a thin layer for air drying till the seeds gained their original moisture content. These hardened seeds were then placed for germination in laboratory under controlled condition. The observations on germination percentage, speed of germination, Mean germination time, coefficient of velocity of germination, Germination index, root length, shoot length, seedling length, root shoot ratio, seedling fresh weight, seedling dry weight, vigour index I and vigour index II (Abdul-Baki and Anderson, 1973) were recorded in this experiment. The experimental data were subjected to analysis of Analysis of variance, mean, standard error, critical difference, coefficient of variation (Fischer, 1936).

\section{Results and Discussion}

According to the results, all studied traits except root shoot ratio were affected by the treatments and there was significant difference between control (unhardened seeds) and hardened seeds. In general, most of the treatments have increased germination and vigour parameters as compared to control (untreated seeds). 
Table.1 Mean performance of various hardening treatments on different seed quality characters of chickpea seed

\begin{tabular}{|c|c|c|c|c|c|c|c|c|c|c|c|c|c|c|}
\hline $\begin{array}{l}\text { S. } \\
\text { No }\end{array}$ & $\begin{array}{l}\text { Treatment } \\
\text { symbol }\end{array}$ & $\begin{array}{c}\text { Germination } \\
(\%)\end{array}$ & $\begin{array}{c}\text { Speed of } \\
\text { Germination }\end{array}$ & MGT & CVG & GI & $\begin{array}{c}\text { Root } \\
\text { length } \\
\text { (cm) }\end{array}$ & $\begin{array}{c}\text { Shoot } \\
\text { Length } \\
\text { (cm) }\end{array}$ & $\begin{array}{l}\text { Seedling } \\
\text { length } \\
(\mathrm{cm})\end{array}$ & $\begin{array}{c}\text { Root } \\
\text { shoot } \\
\text { ratio }\end{array}$ & $\begin{array}{c}\text { Fresh } \\
\text { wt of } \\
\text { seedling } \\
\text { (g) }\end{array}$ & $\begin{array}{l}\text { Dry wt } \\
\text { of } \\
\text { seedling } \\
\text { (g) }\end{array}$ & $\begin{array}{c}\text { Seed } \\
\text { vigour } \\
\text { index- } \\
\text { I }\end{array}$ & $\begin{array}{c}\text { Seed } \\
\text { vigour } \\
\text { index- } \\
\text { II }\end{array}$ \\
\hline 1 & $\mathrm{~T}_{0}$ & 79 & 32.75 & 6.04 & 16.57 & 520.7 & 11.30 & 9.02 & 20.32 & 1.25 & 9.13 & 1.49 & 1603.65 & 117.7 \\
\hline 2 & $\mathrm{~T}_{1}$ & 94.3 & 38.40 & 5.93 & 16.88 & 620.5 & 14.85 & 12.84 & 27.69 & 1.16 & 10.40 & 2.06 & 2614.86 & 193.5 \\
\hline 3 & $\mathrm{~T}_{2}$ & 98.0 & 42.78 & 5.79 & 17.27 & 697.0 & 16.81 & 14.28 & 31.09 & 1.18 & 11.25 & 2.19 & 3047.42 & 214.5 \\
\hline 4 & $\mathrm{~T}_{3}$ & 94.0 & 37.20 & 5.95 & 16.82 & 600.5 & 12.17 & 12.98 & 25.15 & 0.94 & 10.75 & 1.97 & 2365.63 & 184.5 \\
\hline 5 & $\mathrm{~T}_{4}$ & 97.0 & 41.09 & 5.82 & 17.18 & 665.5 & 16.77 & 13.38 & 30.15 & 1.26 & 11.13 & 2.12 & 2924.30 & 205.2 \\
\hline 6 & $\mathrm{~T}_{5}$ & 85.0 & 35.00 & 6.01 & 16.64 & 558.5 & 12.73 & 11.18 & 23.91 & 1.16 & 9.43 & 1.91 & 2028.76 & 161.4 \\
\hline 7 & $\mathrm{~T}_{6}$ & 80.0 & 38.37 & 5.93 & 16.86 & 616.8 & 13.92 & 12.14 & 26.06 & 1.16 & 9.75 & 1.92 & 2083.84 & 153.2 \\
\hline 8 & $\mathrm{~T}_{7}$ & 81.0 & 35.03 & 6.02 & 16.60 & 562.5 & 12.13 & 10.65 & 22.79 & 1.15 & 7.62 & 1.83 & 1842.60 & 148.0 \\
\hline 9 & $\mathrm{~T}_{8}$ & 95.5 & 40.35 & 5.89 & 16.98 & 656.8 & 13.89 & 11.84 & 25.73 & 1.17 & 10.60 & 2.06 & 2458.47 & 196.9 \\
\hline 10 & $\mathrm{~T}_{9}$ & 94.5 & 37.96 & 5.94 & 16.85 & 611.0 & 13.70 & 12.54 & 26.24 & 1.09 & 10.65 & 2.04 & 2480.23 & 192.6 \\
\hline 11 & $\mathrm{~T}_{10}$ & 96.0 & 40.66 & 5.83 & 17.16 & 662.0 & 15.95 & 13.20 & 29.16 & 1.21 & 11.05 & 2.09 & 2800.49 & 200.8 \\
\hline 12 & $\mathrm{~T}_{11}$ & 93.3 & 37.02 & 5.98 & 16.73 & 593.3 & 15.73 & 12.46 & 28.19 & 1.26 & 10.50 & 1.99 & 2630.57 & 184.9 \\
\hline 13 & $\mathrm{~T}_{12}$ & 95.0 & 39.27 & 5.86 & 17.07 & 639.3 & 12.88 & 9.86 & 22.74 & 1.33 & 10.83 & 1.94 & 2159.64 & 184.1 \\
\hline \multicolumn{2}{|c|}{ Mean } & 90.96 & 38.14 & 5.92 & 16.89 & 615.7 & 14.29 & 12.03 & 26.09 & 1.18 & 10.33 & 2.01 & 2387.73 & 179.81 \\
\hline \multicolumn{2}{|c|}{ S.E.(m) } & 1.142 & 1.812 & 0.053 & 0.152 & 32.69 & 0.782 & 0.530 & 1.013 & 0.08 & 0.60 & 0.114 & 103.13 & 9.89 \\
\hline \multicolumn{2}{|c|}{ S.E. ( diff) } & 1.615 & 2.563 & 0.075 & 0.216 & 46.23 & 1.105 & 0.749 & 1.433 & 0.11 & 0.84 & 0.161 & 145.85 & 13.99 \\
\hline \multicolumn{2}{|c|}{ C.D. At $5 \%$} & 3.279 & 5.203 & 0.153 & 0.438 & 93.86 & 2.244 & 1.521 & 2.909 & N/A & 1.70 & 0.33 & 296.13 & 28.42 \\
\hline \multicolumn{2}{|c|}{ C.V. } & 2.511 & 9.5 & 1.794 & 1.806 & 10.62 & 11.12 & 8.809 & 7.765 & 13.2 & 11.58 & 11.58 & 8.63 & 11.00 \\
\hline
\end{tabular}


The study revealed that seeds hardened with $2 \% \mathrm{CaCl}_{2}$ for 12 hours $\left(\mathrm{T}_{2}\right)$ recorded maximum value for Germination percentage (98\%), Speed of germination (42.78), Coefficient of velocity of Germination (17.27), Germination index (697), Shoot length $(14.28 \mathrm{~cm})$, root length $(16.81 \mathrm{~cm})$, Seedling length $(31.09 \mathrm{~cm})$, Seedling fresh weight $(11.25 \mathrm{gm})$, Seedling dry weight $(2.19 \mathrm{gm}), \quad$ Seedling vigour index- I (3047.42), Seedling vigour index- II (214.5) and low Mean germination time(5.79) and second highest was recorded for $\mathrm{KNO}_{3} @ 1 \%$ followed by $5 \%$ Neem leaf extract.

The reason for higher germination percentage and speed of germination may be due to greater hydration of colloids, higher viscosity and elasticity of protoplasm, offer an increase in bound water content, lower water deficit and increased metabolic activity. The improvement in germination by $\mathrm{CaCl}_{2}$ hardened seeds may be attributed to stimulation of hydrolytic enzyme activity known to be induced by $\mathrm{CaCl}_{2}$ agents. Since, calcium in $\mathrm{CaCl}_{2}$ improves cell water status and also acts as cofactors in the activities of numerous enzymes during reserve metabolization and radical protrusion. Higher seedling length including root and shoot length may be due to the enhanced metabolic activity and enzyme activity which hydrolysis the stored reserved food material and make available high energy bio molecules and vital components to growing points and also due to the presence of growth promoting substance $\mathrm{GA}_{3}$, auxin, IAA which induces elongation of cells thereby increasing root and shoot length.

It has been reported that hardened seeds showed better germination pattern and higher vigour level than non- hardened seeds. There are reports that hydration of seeds that equals, but does not exceed, the lag phase of hardening permits early DNA replication, increased RNA and protein synthesis, greater
ATP availability, faster embryo growth, repair of deteriorated seed parts and reduced leakage of metabolites than control.

On the basis of results obtained from the present investigation it is concluded that seed hardening treatment played an effective role in improving Germination and vigour parameters of chickpea seeds. Pre sowing seed hardening with $2 \% \mathrm{CaCl}_{2}$ was found to be suitable among all other treatments and showed superior performance on seed quality parameters of chickpea seeds followed by $1 \%$ $\mathrm{KNO}_{3}$ and $5 \%$ Neem leaf extract. Improvement of seed quality by seed hardening with $2 \% \mathrm{CaCl}_{2}$ is a simple and easy approach to enhance the seed performance and agricultural productivity especially in the dry lands and marginal lands of resource poor farmers and also Calcium chloride helps in strengthening the cell membrane integrity and permeability. Hence, the seed hardened with $2 \% \mathrm{CaCl}_{2}$ is recommended to enhance the seed quality parameters of Chickpea.

\section{References}

Abdul-Baki, A. A., and Anderson, J. D. (1973). Vigor determination in soybean seed by multiple criteria 1. Crop science, 13(6), 630-633.

Ananthi, M., Sasthri, G., Srimathi, P., and Malarkodi, K. (2017). Influence of seed hardening and integrated seed treatment on seed yield and quality in green gram. $J$. Chem. Stud, 5(4), 1945-1948.

Basavegowda, Enayat, Seema Beedi, Sangeetha Macha, Umesh Hiremath and Harish, M.S. 2019. Studies on Enhancing Seed Performance of Kabuli Chickpea. Int.J.Curr.Microbiol.App.Sci. 8(04): 507512

Basra S. M. A.; Farooq, M.; Tabassum, R. (2005). Physiologicaland biochemical aspects of seed vigor enhancement treatments in fine rice (Oryza sativa L.). Seed Science and Technology, 3: 29-33

Chauhan, J. S., Singh, B. B., and Gupta, S. (2016). 
Enhancing pulses production in India through improving seed and variety replacement rates. Indian $J$ Genet Plant Breed, 76(4), 410-419.

Fisher R.A., 1936. "The use of multiple measurements in taxonomic problems." Annals of Eugenics 7: 179- 188.

Food and Agriculture Organization Statistics, 2012; Available at: http://www.fao.org/faostat/en/\#data/QC.

Food and Agriculture Organization Statistics, 2018; Available at: http://www.fao.org/faostat/en/\#data/QC.

JA Samal, RS Bhadane, DB Patel. 2019 Influence of seed hardening on growth and yield of chickpea var. GG-2 (Cicer arietinum L.). Int J Chem Stud;7(4):1756-1759.

Kavitha, S., Bhaskaran, M., and Vanangamudi, K. (2013). Effect of Seed Hardening and Film Coating on Crop Growth and Yield of Sorghum cv. CO (S) 28 under Neyveli Lignite Mine Spoil Condition. Journal of Academia and Industrial Research (JAIR), 2(7), 417.

Manjunath, B. L., and Dhanoji, M. M. (2011). Effect of Seed Hardening with Chemicals on Drought Tolerance Traits and Yield in Chickpea.(Cicer arietinum. L). Journal of Agricultural Science, 3(3), 186.

Nakade, S. B.(2014) Effect of seed hardening on growth, seed yield and seed quality of Chickpea under rainfed condition. (Doctoral dissertation, Mahatma Phule Krishi Vidyapeeth, Rahuri.).

Narayanareddy, A. B., and Biradarpatil, N. K. (2012). Effect of pre-sowing invigouration seed treatments on seed quality and crop establishment in sunflower hybrid KBSH1. Karnataka Journal of Agricultural Sciences, 25(1).

Prabhu, T., Satheesh Kumar, P., and Kamraj, A. (2018). Effect of presowing chemical and organic seed hardening on seed quality, growth and yield characters in rice cv., IR 36. Plant Archives, 18(1), 266-270.

Saicharan, B., Bara, B. M., Rai, P. K., Nihar, B., and Pramod, R. (2019). Effect of Seed Hardening with Micronutrients and Botanicals on Seed Quality Parameters in Chickpea (Cicer arietinum L.). Int. J. Curr. Microbiol. App. Sci, 8(9), 109-113.

Sandhya, K. V. (2009). Studies on Characterization of Seeds and their relationship with quality traits in soybean [Glycine max (L.) Merrill.] (Doctoral dissertation, University of Agricultural Sciences, Bangalore).

Sankar Ganesh, K., Sundaramoorthy, P., Baskaran, L., Rajesh, M., and Rajasekaran, S. (2013). Effect of pre-sowing hardening treatments using various plant growth hormones on two varieties of green gram germination and seedling establishment. International Journal of Modern Biology and Medicine, 3(2), 78-87.

Yari, L., Aghaalikani, M., and Khazaei, F. (2010). Effect of seed priming duration and temperature on seed germination behavior of bread wheat (Triticum aestivum L.). ARPN Journal of Agricultural and Biological Science, 5(1), 1-6.

\section{How to cite this article:}

Kandula Uma Maheswari, J. Hemasruthi, Arun Kumar Chaurasia, P. Vineela and Bharath Chandu, Y. 2020. Assessment of Seed Hardening Treatments on Seed Quality in Chickpea (Cicer arietinum L.). Int.J.Curr.Microbiol.App.Sci. 9(12): 2716-2721. doi: https://doi.org/10.20546/ijcmas.2020.912.322 